Gut, 1973, 14, 552-554

\title{
Histological changes in the gastric mucosa of chronic gastric ulcer patients treated with carbenoxolone
}

\author{
E. THOMAS', P. HALL, AND I. G. HISLOP \\ From the Departments of Gastroenterology and Pathology, The Queen Elizabeth Hospital, Woodville, South \\ Australia
}

SUMMARY Serial direct vision gastric mucosal biopsies were obtained in 25 patients with a chronic lesser curve gastric ulcer. Morphological changes were assessed 'blind' in 15 patients who received carbenoxolone and in 10 untreated patients.

Chronic gastritis was initially observed 'proximal' and 'distal' to the ulcer in 24 of the 25 patients. The mucosal changes were shown to persist in subsequent biopsies and appeared to be uninfluenced by therapy with carbenoxolone even when the ulcer had healed.

Treatment of gastric ulcers with carbenoxolone has been shown to enhance healing (Doll, Hill, and Hutton, 1965; Horwich and Galloway, 1965; Bank, Marks, Palmer, Groll, and van Eldik, 1967), but its mode of action is uncertain. This study was conducted to investigate whether the drug altered the morphological appearances which have been demonstrated in the gastric mucosa in association with chronic gastric ulcer (Magnus, 1952; Mackay and Hislop, 1966; Thomas, Hall, and Hislop, 1972).

\section{Material and Methods}

Histological changes were studied in 25 patients with a chronic lesser curve gastric ulcer. Initial diagnosis of gastric ulceration was made by radiographic and endoscopic examination. The progress of the ulcer was assessed by repeating the gastroscopic examination at three to eight weeks in all patients. In five patients, a third gastroscopic examination was performed six to 10 weeks later.

Fifteen patients, 12 males and three females, aged 35-70 years (mean 55 years), were treated with carbenoxolone. Each patient received $100 \mathrm{mg}$ three times daily from the time of diagnosis until reinspection three to eight weeks later. The untreated group consisted of four males and six females, aged

1Present address: Department of Medicine, Section of Gastroenterology, New York Medical College, New York, 10029.

'Please address requests for reprints to Dr I. G. Hislop, Gastroenterology Unit, The Queen Elizabeth Hospital, Woodville, South Australia. 5011.

Received for publication 18 April 1973.
40-75 years (mean 58.5 years). In these patients the drug was not administered because of coexistent cardiac, hepatic, or hypertensive disease (seven patients). Three patients whose age exceeded 65 years were not treated. All patients had received a variety of antacid medications and five from each of the carbenoxolone-treated and untreated groups had taken an anticholinergic.

Direct vision gastric mucosal biopsies were obtained using the Olympus oesophagoscope (EF). At each examination one specimen was obtained approximately $2 \mathrm{~cm}$ from the ulcer margin (proximal), and another from the opposite wall of the stomach body remote from the ulcer (distal). Biopsy size ranged between 0.2 and $0.5 \mathrm{~cm}$ in diameter.

Histological interpretation of the type of chronic gastritis and degree of cellular infiltration was assessed 'blind' as described previously (Thomas $e t$ al, 1972). Thus, the pathologist (P.H.) did not know from which patient the biopsy was taken, whether the ulcer was active or healing, or whether the patient was receiving carbenoxolone. Chronic superficial gastritis was defined on the basis of normal mucosal thickness, superficial inflammatory and cellular changes with lymphocyte and plasma cell infiltration, and varying degrees of damage and reactive hyperplasia in the epithelium. The presence of reduced mucosal thickness, diffuse infiltration by lymphocytes and plasma cells plus a variable degree of atrophy of the epithelial elements, usually with some evidence of intestinal metaplasia, and sometimes pseudopyloric metaplasia, indicated chronic atrophic gastritis. The severity of cellular infiltration 


\begin{tabular}{|c|c|c|c|c|c|c|c|c|}
\hline \multirow[t]{3}{*}{ Patients } & & \multicolumn{7}{|c|}{ Degree of Cellular Infiltration } \\
\hline & & \multicolumn{2}{|c|}{ Initial Diagnosis } & \multicolumn{2}{|c|}{ At Three to Eight Weeks } & \multicolumn{2}{|c|}{ Six to 10 Weeks Later } & \multirow[t]{2}{*}{ Follow $U p$} \\
\hline & & $P$ & $D$ & $P$ & $D$ & $P$ & $D$ & \\
\hline Treated & $\left\{\begin{array}{r}1 \\
2 \\
3 \\
4 \\
5 \\
6 \\
7 \\
8 \\
9 \\
10 \\
11 \\
12 \\
13 \\
14 \\
15\end{array}\right.$ & $\begin{array}{l}\mathbf{N}- \\
\mathbf{S}+++ \\
\mathbf{S}+ \\
\mathbf{S}+ \\
\mathbf{S}++ \\
\mathbf{S}+++ \\
\mathbf{S}+ \\
\mathbf{S}+ \\
\mathbf{S}+ \\
\mathbf{A}++ \\
\mathbf{S}++ \\
\mathbf{S}+ \\
\mathbf{S}+ \\
\mathbf{S}+++ \\
\mathbf{S}+\end{array}$ & $\begin{array}{l}\mathbf{N}- \\
\mathbf{S}+ \\
\mathbf{S}++ \\
\mathbf{S}+ \\
\mathbf{S}++ \\
\mathbf{S}+ \\
\mathbf{S}+ \\
\mathbf{S}+ \\
\mathbf{S}+ \\
\mathbf{A}++ \\
\mathbf{S}++ \\
\mathbf{S}+ \\
\mathbf{S}+ \\
\mathbf{S}+++ \\
\mathbf{S}+\end{array}$ & $\begin{array}{l}\mathbf{N}- \\
\mathbf{S}+++ \\
\mathbf{S}++ \\
\mathbf{S}+++ \\
\mathbf{S}++ \\
\mathbf{S}+++ \\
\mathbf{S}++ \\
\mathbf{S}+ \\
\mathbf{S}+++ \\
\mathbf{A}++ \\
\mathbf{S}++ \\
\mathbf{S}++ \\
\mathbf{S}+ \\
\mathbf{S}++ \\
\mathbf{S}+\end{array}$ & $\begin{array}{l}\mathbf{S}+ \\
\mathbf{S}+ \\
\mathbf{S}+ \\
\mathbf{S}+++ \\
\mathbf{S}++ \\
\mathbf{S}+ \\
\mathbf{S}++ \\
\mathbf{S}+ \\
\mathbf{S}+++ \\
\mathbf{A}++ \\
\mathbf{S}++ \\
\mathbf{S}++ \\
\mathbf{S}+ \\
\mathbf{S}++ \\
\mathbf{S}+\end{array}$ & $\begin{array}{l}\mathbf{S}++ \\
\mathbf{S}+ \\
\mathbf{S}+++ \\
\mathbf{A}++ \\
\mathbf{S}++\end{array}$ & $\begin{array}{l}\mathbf{S}++ \\
\mathbf{S}+ \\
\mathbf{S}+++ \\
\mathbf{A}++\end{array}$ & $\begin{array}{l}\text { Surgery } \\
\text { Surgery } \\
\text { Surgery } \\
\text { Healed } \\
\text { Healed } \\
\text { Not healed } \\
\text { Healed } \\
\text { Healed } \\
\text { Healed } \\
\text { Healed } \\
\text { Healed } \\
\text { Healed } \\
\text { Healed } \\
\text { Healed } \\
\text { Healed }\end{array}$ \\
\hline Untreated & $\left\{\begin{array}{r}1 \\
2 \\
3 \\
4 \\
5 \\
6 \\
7 \\
8 \\
9 \\
10\end{array}\right.$ & $\begin{array}{l}\mathbf{S}++ \\
\mathbf{S}++ \\
\mathbf{A}++ \\
\mathbf{S}++ \\
\mathbf{A}+++ \\
\mathbf{S}+ \\
\mathbf{S}++ \\
\mathbf{S}+ \\
\mathbf{S}+++ \\
\mathbf{S}+\end{array}$ & $\begin{array}{l}\mathbf{S}+ \\
\mathbf{S}+ \\
\mathbf{S}++ \\
\mathbf{S}++ \\
\mathbf{S}++ \\
\mathbf{S}++ \\
\mathbf{S}++ \\
\mathbf{S}+ \\
\mathbf{S}+++ \\
\mathbf{S}+\end{array}$ & $\begin{array}{l}\mathbf{S}++ \\
\mathbf{S}+++ \\
\mathbf{A}+ \\
\mathbf{S}++ \\
\mathbf{A}++ \\
\mathbf{S}+ \\
\mathbf{S}++ \\
\mathbf{S}+ \\
\mathbf{S}++ \\
\mathbf{S}+\end{array}$ & $\begin{array}{l}\mathbf{S}+ \\
\mathbf{S}++ \\
\mathbf{S}+ \\
\mathbf{S}++ \\
\mathbf{S}++ \\
\mathbf{S}+ \\
\mathbf{S}++ \\
\mathbf{S}+ \\
\mathbf{S}++ \\
\mathbf{S}+\end{array}$ & $\mathbf{A}++$ & $\mathbf{S}+++$ & $\begin{array}{l}\text { Surgery } \\
\text { Healed } \\
\text { Healed } \\
\text { Surgery } \\
\text { Healed } \\
\text { Healed } \\
\text { Healed } \\
\text { Healed } \\
\text { Healed } \\
\text { Healed }\end{array}$ \\
\hline
\end{tabular}

Table Morphology of the gastric mucosa in 15 patients treated with carbenoxolone compared with 10 untreated patients

P 'proximal' biopsy site, D 'distal' biopsy site, $\mathbf{N}$ normal, $\mathbf{S}$ chronic superficial gastritis, A chronic atrophic gastritis, + Denotes cellular infiltration.

was graded semi-quantitatively as mild, moderate, or marked, depending on the number of mononuclear cells in the lamina propria. Special stains for mucin were not carried out as part of this study.

\section{Results}

The table summarizes the results.

Gastroscopic examination at three to eight weeks revealed complete healing in 11 of 15 patients treated with carbenoxolone and in eight of 10 patients who did not receive the drug. Three of the four patients on carbenoxolone whose ulcer failed to heal underwent surgery and one who refused operation was lost to follow up. Resection was performed on the two patients with persisting ulceration in the untreated group. These subjects were not randomized and no conclusion can be drawn as to healing rates in the two groups.

Chronic gastritis was present in both proximal and distal biopsies in 24 patients; in one patient the mucosa was normal at both sites. In the 'proximal' site, chronic superficial gastritis was noted in 21 cases and three had chronic atrophic gastritis. In the 'distal' biopsy, chronic superficial gastritis was observed in 23 patients and chronic atrophic gastritis in one. Sub- sequent 'blind' interpretation of the biopsies at three to eight weeks and on follow up demonstrated persistence of the gastritis in all patients and the pathologist was unable to indicate which patient had received carbenoxolone therapy or whether the ulcer had healed. In the initial biopsy, the mononuclear cell infiltration of the lamina propria appeared to be heavier than normal in both 'proximal' and 'distal' sites in 24 patients. Only minor variations in round cell infiltration were recorded in the subsequent biopsies and again no distinction could be found between the patients who received carbenoxolone and those who did not. In 10 patients the 'proximal' biopsy revealed pyloric gland tissue; fundic gland tissue was present in 10 and in the remaining five the biopsy was considered to be from the junctional region between the two histological types.

\section{Discussion}

Gastritis has been shown to occur in association with gastric ulcers (Ball and James, 1961 ; DuPlessis, 1965) and its persistence has been demonstrated both during and after healing of the ulcer (Palmer, 1951; Salupere, 1969; Thomas et al, 1972). Goodier (1968) 
carried out a histological study on the gastrectomy specimens of 16 gastric ulcer patients treated with carbenoxolone. The presence of gastritis was noted in all specimens, an observation which has been confirmed by our study.

The methodology of investigating the action of carbenoxolone on gastric mucosa by biopsy interpretation has limitations. Previous studies of biopsy material have revealed the patchiness of the mucosal change in gastritis, but have nevertheless established that a single biopsy provides reliable information on the general histological appearance in about $80 \%$ of cases (Joske, Finckh, and Wood, 1955; Williams, Edwards, Lewis and Coghill, 1957). Thus, certain inferences may be drawn from this study which has been unable to demonstrate any effect of carbenoxolone upon the histology of the gastric mucosa either during or after the process of ulcer repair. This supports our previous conclusions (Thomas et al, 1972) that the relationship between gastritis and gastric ulcer is uncertain, for the morphological changes in the gastric mucosa persist unaltered even under the influence of a drug which has been shown to promote healing (Doll et al, 1965; Horwich and Galloway, 1965).
References

Ball, P. A. J., and James, A. H. (1961). The histological background to gastric ulcer. Lancet, 1, 1365-1367.

Bank, S., Marks, I. N., Palmer, P. E. S., Groll, A., and van Eldik, E. (1967). A trial of carbenoxolone sodium in the treatment of gastric ulceration. S. Afr. med. J., 41, 297-300.

Doll, R., Hill, I. D., and Hutton, C. F. (1965). Treatment of gastric ulcer with carbenoxolone sodium and oestrogens. Gut, 6, 19-24.

DuPlessis, D. J. (1965). Pathogenesis of gastric ulceration. Lancet, 1 , 974-978.

Goodier, T. E. W. (1968). Histopathology of gastric ulcers treated with carbenoxolone. In $A$ Symposium on Carbenoxolone Sodium, edited by J. M. Robson and F. M. Sullivan, pp. 111-126. Butterworths, London.

Horwich, L., and Galloway, R. (1965). Treatment of gastric ulceration with carbenoxolone sodium: clinical and radiological evaluation. Brit. med. J., 2, 1274-1277.

Joske, R. A., Finckh, E. S., and Wood, I. J. (1955). Gastric biopsy: a study of 1000 consecutive successful gastric biopsies. Quart. J. Med., 24, 269-294.

Mackay, I. R., and Hislop, I. G. (1966). Chronic gastritis and gastric ulcer. Gut, 7, 228-233.

Magnus, H. A. (1952). Gastritis. In Modern Trends in Gastroenterology, edited by F. Avery Jones, 1st series, pp. 323-351. Butterworths, London.

Palmer, E. D. (1951). On the morphologic state of the gastric mucosa in the duodenal-ulcer patient. Gastroenterology, 18, 8-20.

Salupere, V. (1969). Gastric biopsy in peptic ulcer: a follow up study. Scand. J. Gastroent., 4, 537-543.

Thomas, E., Hall, P., and Hislop, I. G. (1972). Observations on the histology of the gastric mucosa in chronic gastric ulcer. Amer. J. dig. Dis., 17, 683-688.

Williams, A. W., Edwards, F., Lewis, T. H. C., and Coghill, N. F. (1957). Investigation of non-ulcer dyspepsia by gastric biopsy. Brit. med. J., 1, 372-377. 